\title{
Effect of Ammonium on the Hydraulic Conductivity of Kaolin and Bentonite as Clay Liners
}

\author{
Adekunle Adebola Adebayo ${ }^{1}$, Igba Uvieoghene Tobit ${ }^{1}$, and Ogunrinola Oluwaseyi Gbemiga ${ }^{1}$ \\ 1- Department of Civil Engineering, Federal University of Agriculture, Abeokuta, Nigeria \\ Corresponding author contact: adebolamay@gmail.com
}

\begin{abstract}
Landfill liners are underlying materials with low permeability whose main function is to mitigate the infiltration of toxic contents into ground water lying beneath. Landfill liners are primarily made of bentonite clay. Bentonite has a very low hydraulic conductivity, that might not be readily accessible, unlike kaolin which is found to have a lower hydraulic conductivity compared to that of bentonite and can be extensively obtained from numerous different sources. Explored, for the purposes of the present research paper, were various ratios of bentonite and kaolin and their hydraulic conductivity, in particular ratios of 90:10 kaolin to bentonite, 80:20 kaolin to bentonite, 70:30 kaolin to bentonite, 60:40 kaolin to bentonite and 50:50 kaolin to bentonite in an effort to achieve an acceptable barrier suitable as a liner / where tap water and ammonium solution were used as permeants. It was concluded that the ratios not lower than $20 \%$ bentonite $(80: 20,70: 30,60: 40$ and 50:50) all had their hydraulic conductivity value reduced compared to the $100 \%$ kaolin.
\end{abstract}

Keywords: Hydraulic conductivity, bentonite, kaolin, clay liner.

\section{Introduction}

In the attainment of adequate management of waste and sustainable resource recovery, landfill might have an important role to play. Disposal of waste in an environmentally friendly and safe manner remains a major challenge for all nations. Landfill, which is primarily used to store waste that cannot be minimized, reused, recycled or recovered requires an effective lining system in order to reduce pollutant leakage, safeguard groundwater, and the surrounding environment (Karunaratne et al, 2001).

The primary purpose of the landfill liner systems is to minimize or prevent the passage of leachate into the ground. As these leachates pass through, they get treated before mixing with groundwater. Since landfills are built to protect the environment by isolating waste, the design of a top cover might become necessary so as to minimise water infiltration into the landfill. This is because when water enters a landfill and mixes with waste, it adds up to the quantity of leachate already produced within waste. The bottom liners designed and installed in landfills will then serve as a leachate containment system to improve its removal for further treatment. The mixture of clay/bentonite and sand as construction material for various engineering applications like containment of waste has been practiced for decades. The swelling property of bentonite makes it possible for it to fill the voids within sand particles therefore making its mixture with sand to form a low permeable membrane (Ghazi, 2015).

Landfill leachate contains multiple pollutants of high concentration. Chemical reactions such as ion exchange, dissolution, biochemical processes, and precipitation affects the hydraulic conductivity soils when leachate is transferred through the clay liner and underlying soil (Yilmaz et al., 2008). Hydraulic conductivity which is a measure of the ratio of the velocity of hydraulic gradient signifies how permeable a porous media is. In simpler terms, it is said to be the rate at which fluid passes through a sample. Vertical barriers (cutoff walls) have been used extensively since the 1970's to contain subsurface pollutants in-situ and control groundwater. For example, in the United States, sand-bentonite (SB) slurry trench cutoff wall named after the type of barrier material and the construction method (slurry trench) has become the most common form of vertical barrier (LaGrega et al., 2001). 
The mechanical and physicochemical factors of soil particles regulat the hydraulic conductivity of the soils. The mechanical variables are related to soil grain size, forms, and geometrical structures. The physicochemical variables refer to soil water attraction and cations to the surfaces of clay particles. They tend to forman "electrical double layer" around the soil particles, and the adsorption of the water is of sufficient strength that both the soil particles and the double layer serve to block the flow paths. The thicker the double layer, the narrower and more indirect the paths of flow through the soil, which lowers the hydraulic conductivity (Daniel, 1994). Bentonite has a standard hydraulic conductivity $\mathrm{K}<10^{-10} \mathrm{~m} / \mathrm{s}$ and Kaolin has a hydraulic conductivity not greater than $6.0 \times 10^{-8} \mathrm{~m} / \mathrm{s}$. Bentonite has a low hydraulic conductivity and is known to serve as a suitable barrier for landfills but due to its easy inaccessibility, it is used with kaolin which is abundant. This research outlines the changes detected in hydraulic conductivity and other significant index properties when ammonia permeant is passed through bentonite:kaolin mixtures when used as clay liner.

Ammonia is said to naturally exist in the environment and in humans and it is vital for several biological processes. The production of ammonia in the environment happens naturally through organic matter (such as, plants, animals and their waste) decomposition. Although, its presence in humans is very minimal since it is highly toxic and can lead to a disturbance of consciousness, coma or even convulsion if large amount of it is ingested.

The hydraulic conductivity determines the ability of municipal solid waste (MSW) leachate to flow through compacted soil matrix system under hydraulic gradient. Borgadi et al., (1989) stated that hydraulic conductivity was considered as a basic parameter in the design of hydraulic barrier systems and for characterizing liner performance and reliability.

Low hydraulic conductivity was essential in the design of waste disposal facilities, especially in the case of the clay to be used in lining (Qiang, 2015).

Compacted fine-grained clay soils were widely used as soil liners and covering in the floor of waste containment structures or landfills. The primary purpose was to minimize some contamination to the natural ground water caused by the leachate permeation. The hydraulic conductivity value of compacted clay liner assumed utmost importance (Daniel, 1987).

The results of the hydraulic conductivity tests conducted in the laboratory on compacted specimens were utilized in determining the compaction criterion for each soil and the compaction criterion then served as a guide for the construction of covers and soil liners in the field (Nwaiwu et al., 2005).

Daniel (1993) showed that bentonite clay materials were the preferred hydraulic barriers due to their good adsorption/retention capacity and low hydraulic conductivity. The assessment of hydraulic conductivity is typically done by carrying-out a compatibility test where the specimen gets permeated with a sample of liquid simulating the anticipated liquid or the exact liquid to be contained. These liquids are then referred to as "non-standard liquids" so as to differentiate them from standard liquids like tap water, distilled water, deionized water, or a standard water, such as the $0.05 \mathrm{~N} \mathrm{CaSO}_{4}$ solution prescribed in ASTM D 5084 (2010).

\subsection{Materials and Methodology \\ 2.1 Materials}

The materials utilized in this research were kaolin and bentonite used as clay liners, where tap water and ammonium solution were used as permeants. The tests carried out involved specific gravity tests, compaction test, Atterberg's limits, sieve analysis, natural moisture content and X-ray fluorescence. Below is a brief explanation of the materials used, their properties, and the tests carried out.

\subsubsection{Bentonite}

Bentonite, being a soft material while in its natural state, dissociate in water leaving a distinct greasy impression upon touching it. Due to the nature of its grains being quite small and a contact surface area being large, its water retention potential is high. Also, its ability to swell and being a highly plastic material made it a desirable material to be used for various purposes like slurry walls, drilling mud, 
clarification of wine and beer. The samples were not readily available in Ogun State, so it was obtained from Lagos State, Nigeria. The samples used were fine and uniform soil sample. It was brown in color, but with the addition of water, it turned cream, with a very slippery feel and high tendency to clustering. Bentonite passed through a 425 microns sieve.

\subsubsection{Kaolin}

Kaolin which is commonly referred to as china clay contains $10-95 \%$ of the mineral kaolinite and consist mainly of kaolinite (85-95\%). It is a hydrated aluminum silicate with a crystalline structure that allows for a large surface area adsorbing many times its weight in water.

The kaolin used in this study was obtained from Ajebo, Abeokuta in Ogun State in form of large lump of boulders which was later pulverized before it was used. Kaolin is usually in lumps and tends to change color on pulverizing but fully white when grinded. The kaolin samples were pulverized and filtered through $425 \mu \mathrm{m}$ sieve prior to all intended experiments.

The Kaolin and Bentonite were mixed in the following proportions:

- Bentonite 0: 100 Kaolin

- Bentonite 10: 90 Kaolin

- Bentonite 20: 80 Kaolin

- Bentonite 30: 70 Kaolin

- Bentonite 40: 60 Kaolin

- Bentonite 50: 50 Kaolin

- Bentonite 100: 0 Kaolin

In each of the seven cases, tap water and ammonium solution served as permeants which were introduced when they were placed in the permeameter.

\subsubsection{Ammonia $\left(\mathrm{NH}_{4} \mathrm{OH}\right)$}

Ammonia was one the major constituents of leachate (Aluko et al., 2003). Ammonia applied in this study had a concentration of $622.26 \mathrm{mg} / \mathrm{l}$ which was prepared in the laboratory and used as permeant on the soil in each case.

\section{$3 \quad$ Results}

\subsection{Specific gravity test}

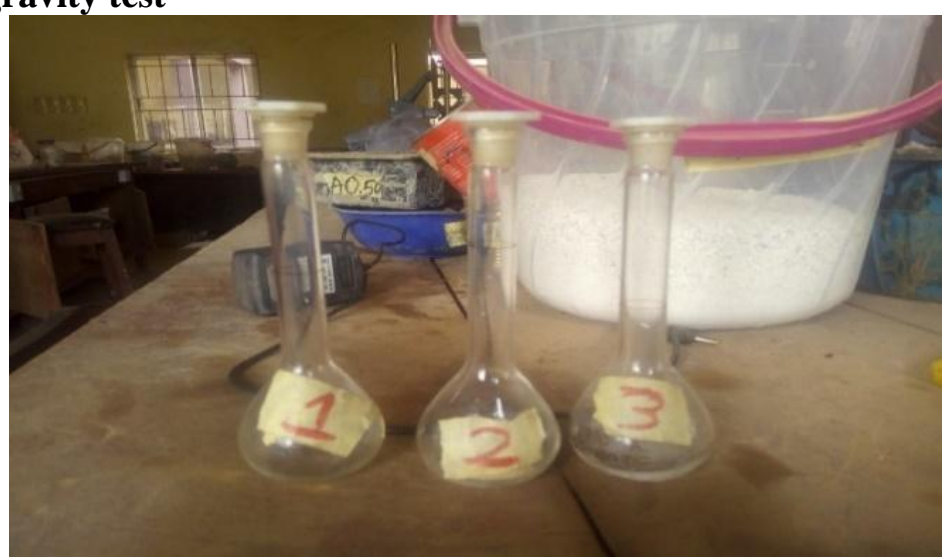

Fig. 1. Specific gravity test of bentonite and kaolin used in the study 
Table 1. Specific gravity of the bentonite : kaolin mixtures used in the study

\begin{tabular}{|c|c|c|c|c|c|c|c|}
\hline $\begin{array}{c}\text { Bentonite: } \\
\text { Kaolin } \\
\text { Ratio }\end{array}$ & $\mathbf{0 : 1 0 0}$ & $\mathbf{1 0 0 : 0}$ & $\mathbf{1 0 : 9 0}$ & $\mathbf{2 0 : 8 0}$ & $\mathbf{3 0 : 7 0}$ & $\mathbf{4 0 : 6 0}$ & $\mathbf{5 0 : 5 0}$ \\
\hline $\begin{array}{c}\text { Specific } \\
\text { gravity }\end{array}$ & 2.7900 & 2.5906 & 2.7360 & 2.6963 & 2.5866 & 2.5333 & 2.525 \\
\hline
\end{tabular}

From the table above, it can be deduced that kaolin had a higher density compared to bentonite.

The result showed that bentonite caused a reduction in the value compared to that of kaolin.

Specific gravity test conducted showed that kaolin was heavier than bentonite. On the addition of bentonite to kaolin, there was a decrease in the specific gravity, it was observed that bentonite clay contained more voids than kaolin clay.

When $10 \%$ of bentonite was added to $90 \%$ of kaolin, no drastic change occurred compared to when $50 \%$ of kaolin and $50 \%$ bentonite were added together.

Hence, kaolin was denser than bentonite. As it was even when compacted, it tended to serve as a better barrier for landfills as it was hard for fluids to pass through. (Chen et al, 2002)

\subsection{Natural moisture content}

Table 2. Natural moisture content of kaolin and bentonite

\begin{tabular}{|c|c|}
\hline Soil Samples & Moisture Content (\%) \\
\hline Kaolin & 3.00 \\
\hline Bentonite & 2.23 \\
\hline
\end{tabular}

This was the first test conducted as samples were obtained from sources.

As each sample was obtained, they were taken in small quantities and subjected to heat using the oven at about $100^{\circ} \mathrm{C}$ for more than 16 hours.

On retrieval, it was established that Kaolin in its natural state, undisturbed tended to allow more moisture within itself compared to the industrial bentonite. 


\subsection{Compaction}

Table 3. Optimum Moisture Content and Maximum Dry Density of Kaolin and Bentonite

\begin{tabular}{|c|c|c|}
\hline & Kaolin & Bentonite \\
\hline Maximum Dry Density $\left(\mathrm{g} / \mathrm{cm}^{3}\right)$ & 1.8 & 1.5 \\
\hline Optimum Moisture Content $(\%)$ & 20.5 & 12.9 \\
\hline
\end{tabular}

Clearly, not only the maximum dry density but also the optimum moisture content were measures of compaction as they both maintained a definite relationship on how soil samples retained moisture.

Just as furthermore, the moisture content showed that kaolin was likely to retain a higher percentage of water compared to bentonite, which was also in line with the natural moisture content.

Kaolin was able to retain $7.6 \%$ more moisture compared to bentonite.

The maximum density indicated that more amount of kaolin was needed to achieve a well compacted bentonite to prevent fluid passage compared to bentonite.

\subsection{Atterberg limits tests}

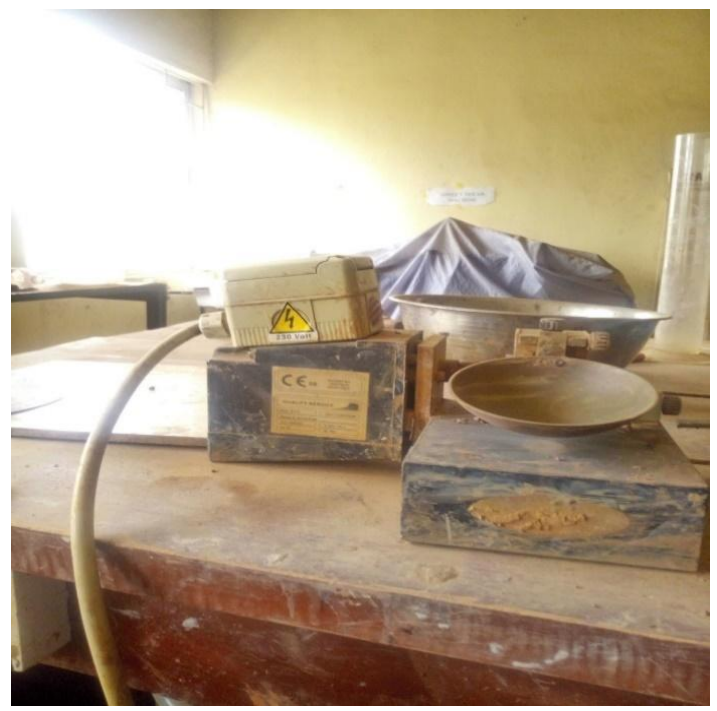

Fig. 2. The apparatus of Atterberg limits test used in the study

Table 4. Liquid limits, plastic limits and plastic index of kaolin and bentonite

\begin{tabular}{|c|c|c|}
\hline Soil Samples & Kaolin (\%) & Bentonite (\%) \\
\hline Liquid Limit & 69 & 215 \\
\hline Plastic Limit & 30 & 70.5 \\
\hline Plastic index & 39 & 144.5 \\
\hline
\end{tabular}


Both plastic and liquid gave an insight on the increment of the moisture content which caused the soil to behave in a plastic manner.

Kaolin (100\%) absorbed $30 \%$ before it started failing when being tried to roll into threads.

Bentonite $(100 \%)$ on the other hand had the tendency to take up to $70 \%$ of the moisture before it started smearing on the surface in which it was rolled.

Kaolin: Bentonite (90:10) had a capacity of 66\%. For kaolin: Bentonite 80:20,70:30,60:40 and 50:50, as the bentonite percentage increased, the plastic and liquid limit increased in each case.

Table 5. Kaolin:Bentonite Mixtures Index Properties used in the study

\begin{tabular}{|c|c|c|c|c|c|}
\hline $\begin{array}{c}\text { Soil Samples } \\
\text { (Kaolin: } \\
\text { Bentonite) }\end{array}$ & $\mathbf{9 0 : 1 0}$ & $\mathbf{8 0 : 2 0}$ & $\mathbf{7 0 : 3 0}$ & $\mathbf{6 0 : 4 0}$ & $\mathbf{5 0 : 5 0}$ \\
\hline Liquid Limit & 66 & 65 & 89 & 110 & 200 \\
\hline Plastic Limit & 36 & 31 & 35 & 49.1 & 60.6 \\
\hline Plastic Limit & 36 & 31 & 35 & 49.1 & 60.6 \\
\hline
\end{tabular}

It was noticed that when the ratio of kaolin to bentonite was 60:40 and 50:50, the clay of kaolin when rolled out, behaved almost like that of bentonite as there was much difficulty in rolling as they smeared on surfaces with ease.

It can be inferred that bentonite played significant role in the increment of the moisture content.

\subsection{X-Ray Fluorescence}

Table 6. Chemical composition of Kaolin

\begin{tabular}{|c|c|c|}
\hline Element & Without Ammonia & With Ammonia \\
\hline $\mathrm{SiO}_{2}$ & 0.01 & 0.01 \\
\hline $\mathrm{Al}_{2} \mathrm{O}_{3}$ & 0.01 & trace \\
\hline $\mathrm{Fe}_{2} \mathrm{O}_{3}$ & trace & trace \\
\hline $\mathrm{TiO}_{2}$ & trace & trace \\
\hline $\mathrm{CaO}$ & trace & trace \\
\hline $\mathrm{P}_{2} \mathrm{O}_{5}$ & - & trace \\
\hline $\mathrm{K}_{2} \mathrm{O}$ & trace & trace \\
\hline $\mathrm{MnO}$ & - & trace \\
\hline $\mathrm{MgO}$ & trace & trace \\
\hline $\mathrm{Na} 2$ & trace \\
\hline $\mathrm{LOI}$ & trace & trace \\
\hline $\mathrm{Ba}$ & 0.07 & trace \\
\hline $\mathrm{Cu}$ & trace & trace \\
\hline $\mathrm{Cr}$ & 0.01 & trace \\
\hline $\mathrm{Ni}$ & trace & \\
\hline
\end{tabular}




\begin{tabular}{|c|c|c|}
\hline $\mathrm{Zn}$ & 0.03 & trace \\
\hline $\mathrm{Co}$ & - & trace \\
\hline $\mathrm{Sr}$ & - & trace \\
\hline $\mathrm{Pb}$ & - & trace \\
\hline $\mathrm{Sc}$ & - & trace \\
\hline $\mathrm{Cd}$ & - & trace \\
\hline
\end{tabular}

Table 7. Chemical composition of bentonite

\begin{tabular}{|c|c|c|}
\hline Element & With no chemical & With ammonium \\
\hline $\mathrm{SiO}_{2}$ & 0.01 & 0.01 \\
\hline $\mathrm{Al}_{2} \mathrm{O}_{3}$ & trace & trace \\
\hline $\mathrm{Fe}_{2} \mathrm{O}_{3}$ & trace & trace \\
\hline $\mathrm{TiO}_{2}$ & trace & trace \\
\hline $\mathrm{CaO}$ & trace & trace \\
\hline $\mathrm{P}_{2} \mathrm{O}_{5}$ & trace & trace \\
\hline $\mathrm{K}_{2} \mathrm{O}$ & trace & trace \\
\hline $\mathrm{MnO}$ & trace & trace \\
\hline $\mathrm{MgO}$ & trace & trace \\
\hline $\mathrm{Na}_{2} \mathrm{O}$ & trace & trace \\
\hline LOI & trace & trace \\
\hline $\mathrm{Ba}$ & 0.13 & 0.13 \\
\hline $\mathrm{Cd}$ & trace & trace \\
\hline Co1 & trace & trace \\
\hline $\mathrm{Cu}$ & 0.02 & 0.02 \\
\hline $\mathrm{Cr}$ & 0.02 & 0.02 \\
\hline $\mathrm{Nb}$ & trace & trace \\
\hline $\mathrm{Ni}$ & 0.01 & 0.01 \\
\hline $\mathrm{Pb}$ & trace & trace \\
\hline $\mathrm{Sc}$ & 0.01 & 0.01 \\
\hline $\mathrm{Sr}$ & 0.02 & 0.02 \\
\hline $\mathrm{Rb}$ & trace & trace \\
\hline $\mathrm{Zn}$ & 0.01 & 0.01 \\
\hline $\mathrm{Zr}$ & 0.03 & 0.03 \\
\hline
\end{tabular}


From the results in tables 7, about 24 elements were evident in bentonite before and after ammonium was added. The result showed physico significant role as there were no alteration in the chemical composition of the soil sample unlike the kaolin were the elements before the addition of ammonium $\mathrm{Co}, \mathrm{Sr}, \mathrm{Pb}, \mathrm{Sc}, \mathrm{Cd}, \mathrm{MnO}$ and $\mathrm{P}_{2} \mathrm{O}_{5}$ were not present before the sample was permeated with ammonia. There were significant changes in the elemental constituent of kaolin.

Cobalt $(\mathrm{Co})$, Antimony $(\mathrm{Sb})$, Lead $(\mathrm{Pb})$, Scandium $(\mathrm{Sc})$ and Cadmium $(\mathrm{Cd})$ were elements that surfaced after permeating with ammonium. Trace amounts of these element were present but they, however, were made conspicuous by ammonium.

Barium (Ba) was noticed to be in high concentration about 0.07 in Kaolin and 0.13 in the soil samples although there was no concrete evidence as to their impact upon the increase in hydraulic conductivity.

\subsection{Sieve Analysis}

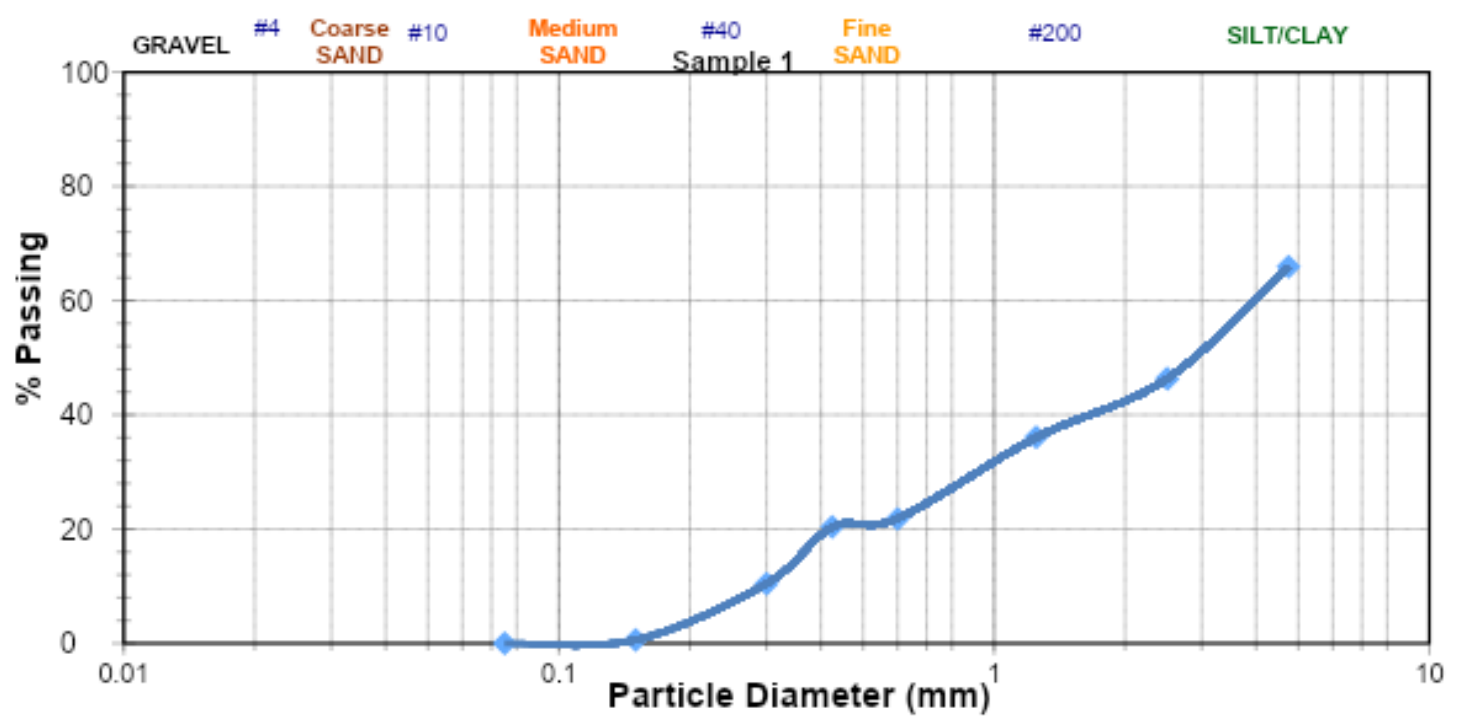

Fig. 3. Particle-size distribution of kaolin clay used in the study

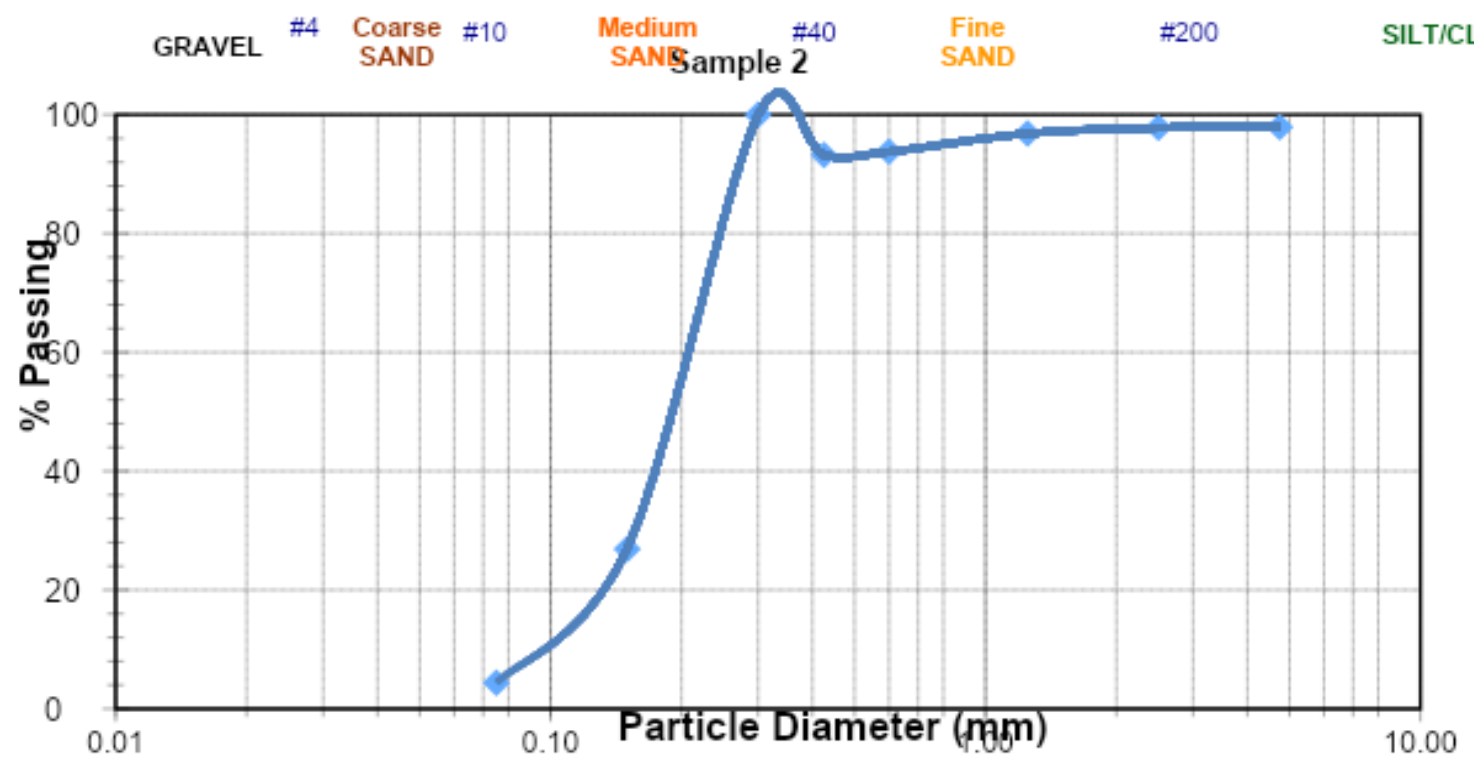

Fig. 4. Particle-size distribution of bentonite clay used in the study 
A visible characteristic of both kaolin and bentonite was their fineness although bentonite gave a smoother feeling compared to kaolin.

On sieving bentonite, about $70.6 \%$ of the sample was noticed to have been retained by the sieve number 200. This showed how fine the soil sample was.

For kaolin, it was described by sieve number 4, 140 and 200 as these were the sieves that were noticed to have retained more soil samples. The number 4 was due to lumps, while 40 and 140 were said to be a characteristic property of kaolin. Sieve 4 retained $33.48 \%$,

From AASHTO (1986) Soil Classification System, it followed that soil with Plastic Index $>11 \%$ was regarded as clayey.

Kaolin had Plastic Index 39 and bentonite with 144.5 all greater than 11.

\subsection{Hydraulic conductivity.}

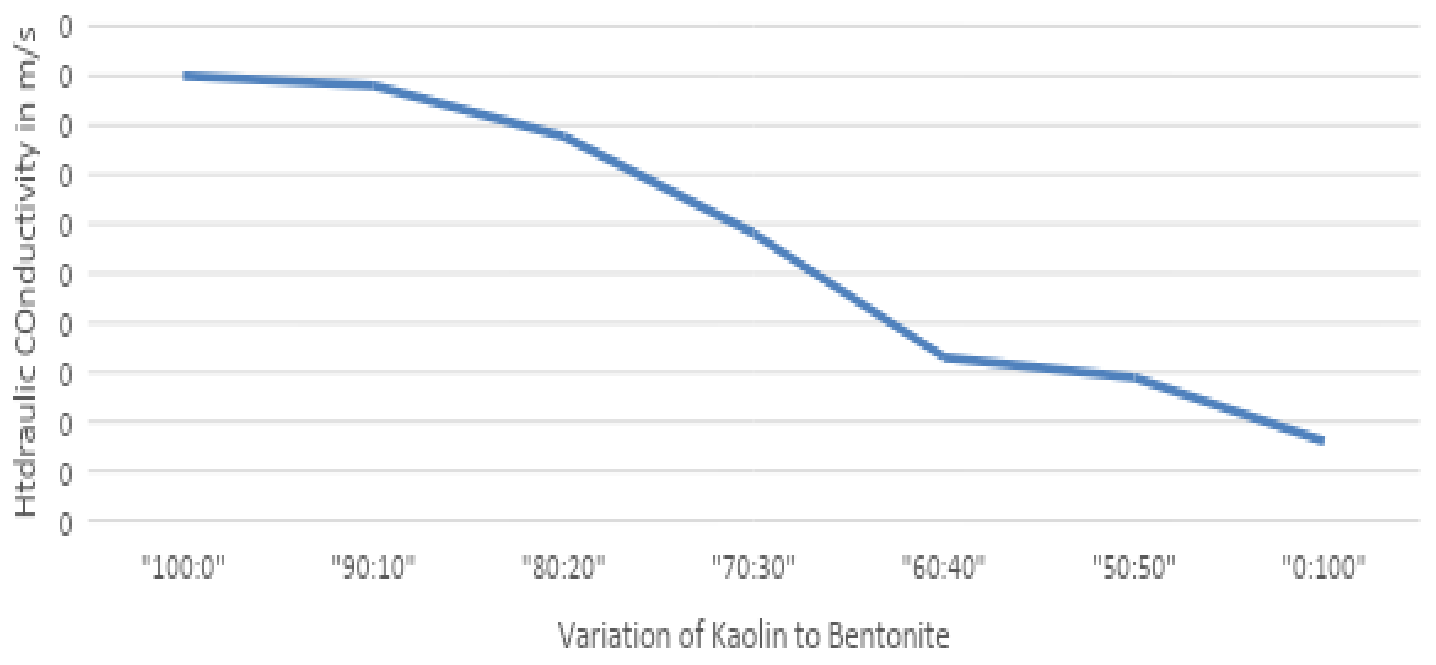

Fig. 5. Kaolin to bentonite variation using tap water vs. Hydraulic conductivity

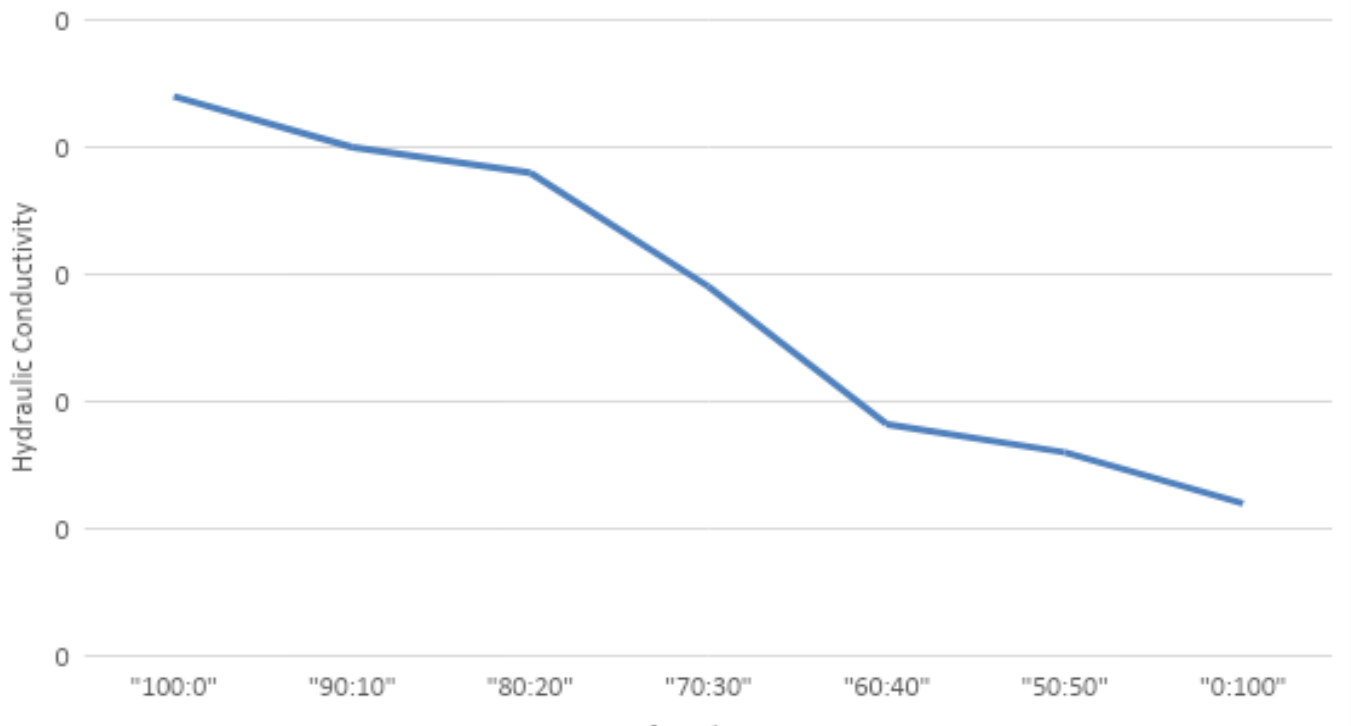

Fig. 6. Kaolin to bentonite variation bentonite using ammonium solution vs. Hydraulic conductivity 
In the present paper, the hydraulic characteristic values for kaolin:bentonite mixtures using permeants of tap water and ammonia solution were shown in Figures 5 and 6, respectively. For figure 5, when tap water was used as permeant, it showed that 100\% kaolin and 90:10 behaved approximately a hydraulic conductivity of $1.8 \times 10^{-9} \mathrm{~m} / \mathrm{s}$ which was the highest and sample kaolin and bentonite in the ratio 50:50 had the lowest of $5.8 \times 10^{-10} \mathrm{~m} / \mathrm{s}$. these were the range of the hydraulic conductivity. When ammonia was used as permeant, the range of values were between $2.2 \times 10^{-9} \mathrm{~m} / \mathrm{s}$ and $6.0 \times 10^{-10} \mathrm{~m} / \mathrm{s}$.

\section{Conclusions}

From the various experiments conducted, it can be concluded that the increase in the amount of bentonite in each ratio enhanced the plastic properties of the samples weakening the specific gravity. Accordingly, the consistency of each sample was reduced in each case.

It should also be ascertained that as the plasticity index increased, the hydraulic conductivity decreased.

At Ratios less than $30 \%$, it was established that

-The hydraulic conductivities were high compared to that of bentonite when ammonium solution was used as permeant

- The hydraulic conductivities were on a very close range when tap water was used as permeant

Kaolin mixed with 30-50\% bentonite proportion can therefore be used as a liner material for landfills. Also, as the amount of bentonite proportion increased, the consistency of each composition increased.

90:10 Kaolin to Bentonite ratio might not be suitable when compared to the more appropriate alternative of 50:50 Kaolin to bentonite ratio. This, undoubtedly, was due to the stronger presence of kaolin to bentonite in the mixture.

\section{References}

AASHTO (1986), Standard Specifications for Transportation Materials and Methods of Sampling and Testing,14th Edition, American Association of State Highway and Transportation Officials, Washington, D.C.

ASTM D5084 (2010). Standard Test Methods for Measurement of Hydraulic Conductivity of Saturated Porous Materials Using a Flexible Wall Permeameter, Vol. 04.08, American Society for Testing Materials

Aluko, O.O., Sridhar, M.K.C., and Oluwande, P.A. (2003). Characterization of leachates from a municipal solid waste landfill site in Ibadan, Nigeria. Journal of Environmental Health Research, Volume 2, Issue 1.

Borgadi, I., Kelly, W.E. \& Wang, X. (1989), "Reliability Model for Soil Liners", Journal of Geotechnical and Geoenvironmental Engineering, ASCE, 115(5), 658-669. https://doi.org/10.1061/(ASCE)0733-9410(1989)115:5(658)

Chen. J., Chen, Anandarajah, A., and Inyang, H. (2002). Discussion of "Pore Fluid Properties and Compressibility of Kaolinite" Journal of Geotechnical and Geoenvironmental Engineering Volume 128 Issue 4 - April 2002 https://doi.org/10.1061/(ASCE)1090-0241(2002)128:4(360) 
Daniel, D., E,. (1987). Earthen liners for land disposal facilities. Geotechnical Practice for Waste Disposal '87, GSP No. 13, ASCE, 21 - 39.

Daniel, D.E. (1993), Geotechnical Practice for Waste Disposal, Chapman and Hall, London, p.683. https://doi.org/10.1007/978-1-4615-3070-1

Daniel, D.E., (1994). State of the art: Laboratory hydraulic conductivity tests for saturated soils, ASTM Special Technical Publication, 1142, 30-30. https://doi.org/10.1520/STP23884S

Ghazi, A. F. (2015). Engineering characteristics of compacted sand-bentonite mixtures. Retrieved from https://ro.ecu.edu.au/theses/1615

Karunaratne, G.P., S.H. Chew, S.L. Lee, and A.N. Sinha. "Bentonite:Kaolinite Clay Liner." Geosynthetics International 8, no. 2 (January 2001): 113-133. https://doi.org/10.1680/gein.8.0189

LaGrega, M.L., Buckingham, P.L., and Evans, J.C. 2001. Hazardous waste management, 2nd ed. McGraw-Hill Book Company, NewYork, N.Y

Nwaiwu, C.M.O., Osinubi, K.J. \& Afolayan, J.O. (2005), "Statistical Evaluation of the Hydraulic Conductivity of Compacted Lateritic Soil", Geotechnical Testing Journal, 28 (6), 586-595. https://doi.org/10.1520/GTJ12130

Qiang, T., Takeshi, K., Toru, I., and Zhenze, Li. (2015). "Membrane behavior of bentonite-amended compacted clay towards $\mathrm{Zn}$ (II) and Pb (II)". Membrane Water Treatment, 6 (5), 393-409. https://doi.org/10.12989/mwt.2015.6.5.393

Y1lmaz, G., Arasan, S. \& Yetimoglu, T. (2008) Effect of $\mathrm{NaCl}$ salt on the permeability of base clay liners in solid waste disposal landfills. Teknik Dergi/Technical Journal of Turkish Chamber of Civil Engineers, 19, 4347-4356, (in Turkish with an English summary). 
